\title{
Temperature and Circulation Dynamics in a Small and Shallow Lake: Effects of Weak Stratification and Littoral Submerged Macrophytes
}

\author{
Péter Torma ${ }^{1}$ (D) and Chin H. Wu ${ }^{2, *(D)}$ \\ 1 Department of Hydraulic and Water Resources Engineering, Budapest University of Technology and \\ Economics, Budapest, Múegyetem rkp. 3, 1111 Hungary, Hungary; torma.peter@epito.bme.hu \\ 2 Department of Civil and Environmental Engineering, University of Wisconsin, Madison, WI 53706, USA \\ * Correspondence: chinwu@engr.wisc.edu; Tel.: +1-608-263-3078
}

Received: 11 December 2018; Accepted: 10 January 2019; Published: 12 January 2019

check for updates

\begin{abstract}
In this paper, the effects of littoral submerged macrophytes on weak stratification conditions in a small and shallow lake are investigated. Diverse submerged macrophytes occupying a large portion of the littoral zone act as resistance to water motions and affect lake hydrodynamics. Strong solar radiation and mild wind forcing typically occurring during the summer season result in weak stratification characterized by a diurnal cycle with a temperature differential of $1-3{ }^{\circ} \mathrm{C}$. Temperature and circulation dynamics of a small and shallow lake are depicted by extensive field measurements and a three-dimensional non-hydrostatic model with a generic length scale (GLS) approach for the turbulence closure and drag forces induced by macrophytes. Results show that the effects of macrophytes on velocity profiles are apparent. In the pelagic area, the circulation patterns with and without macrophytes are similar. The velocity profile is generally characterized by a two-layer structure with the maximum velocity at both the water surface and the mid-depth. In contrast, inside the littoral zone, the mean flow is retarded by macrophytes and the velocity profile is changed to only one maximum velocity at the surface with a steeper decrease until $2.0 \mathrm{~m}$ depth and another slight decrease to the lake bottom. From the whole lake perspective, littoral macrophytes dampen the horizontal water temperature difference between the upwind side and download side of the lake. Macrophytes promote a stronger temperature stratification by retarding mean flows and reducing vertical mixing. Overall, this study shows that the temperature structures and circulation patterns under weak stratification conditions in a small and shallow lake are strongly affected by littoral vegetation.
\end{abstract}

Keywords: small and shallow lake; submerged macrophytes; weak stratification; non-hydrostatic model; circulation pattern; temperature structure

\section{Introduction}

Small shallow lakes are the most abundant lake types in the north temperate landscape. A great deal of research has been conducted on the biology and ecology of small shallow lakes [1-6], but few studies have focused on circulation patterns and thermal structures. Generally, there are two distinguished features in small and shallow lakes. First, weak stratification is commonly observed in a shallow water system (mean depths 3-4 m), where wind- and cooling-induced mixing reaches the lake bottom [7]. This weak stratification modifies the vertical velocity profile, which can affect the spatial distributions of plankton communities [8,9]. Second, submerged macrophytes, common seen in shallow eutrophic lakes, can affect the lake's ecology and water quality $[10,11]$. Littoral macrophytes can form a transition zone between terrestrial and aquatic systems $[12,13]$. The concentration gradient 
in nutrients, sediment and other contaminants between littoral macrophytes and open pelagic zones can be large, causing an active exchange of constituents [14]. Furthermore, rooted plants of the littoral zone can enrich the water with nutrients and organic matter, stimulating pelagic production and sedimentation. In view of this important fact, better understanding the effects of weak stratification and littoral submerged vegetation on the spatial and temporal variability of circulation and temperature in small and shallow lakes is highly desired [15].

Weak thermal stratification with surface-to-bottom temperature differentials of $1-4{ }^{\circ} \mathrm{C}$ has been reported and studied recently [16-21]. In summer seasons, water temperatures closely follow the diurnal cycle of solar radiation and air temperature. Changing meteorological conditions with wind shear at the lake surface can quickly shift from a stratified period to a well-mixed regime on a daily or even hourly basis, depending on the intensity of vertical mixing produced by the wind [22]. Nevertheless, small and shallow lakes, in contrast to large lakes, have short fetches and are usually affected by wind sheltering due to onshore surroundings [20,23]. Reduction of wind-induced mixing can affect temperature stratification to cause active upper layers to be separated from nutrient-rich bottom layers, which is important to biological production and photosynthesis [24]. Overall, the evolving weak stratification, sometimes characterized by a diurnal cycle due to the net surface heat loss during nighttime, can create negative buoyancy fluxes to affect vertical transport and mixing.

Submerged macrophytes play an important role in controlling the transport and spatial distribution of chemical and biological activities through hydrodynamic processes [25]. For example, macrophytes can retard flow velocities [26,27], attenuate surface waves [28] and effectively dampen the wind generated turbulences to penetrate from the surface to greater depths [29]. Consequently, macrophytes can trap and deposit suspended sediments [30] to enhance geomorphic stability [31]. Submerged macrophytes can strengthen daytime stratification due to both reduced wind mixing and increased solar radiation attenuation that result in a higher temperature difference and a stronger near surface stratification [19,32]. In other words, submerged macrophytes can alter the role of wind shear mixing and net heat flux to affect the hydrodynamic characteristics in small and shallow lakes. Macrophytes in the more open and actively turbulent water can act as drag [29]. Macrophytes in the short-fetch and low-turbulence water can promote weak density-driven motions by shading from solar heating. In spite of our knowledge on the role of macrophytes [25-31] in hydrodynamic processes, there are still limited studies that have investigated the dynamics of small shallow lakes with littoral submerged macrophytes.

Previous studies have attempted to reveal the effects of weak stratification and littoral submerged vegetation on temperature and circulation dynamics in small shallow lakes. Herb and Stefan [32] depicted local stratification in the presence of submerged macrophytes by developing a one-dimensional (1D) model with vertical production, transport and dissipation of turbulent kinetic energy caused by different weather conditions. Nevertheless, results cannot explain the situation where there is large horizontal advection in lakes with a non-uniform distribution of macrophytes [33]. Two-dimensional (2D) depth-averaged models were employed to address the horizontal circulation and temperature dynamics [23,34]. Further efforts have been paid to incorporate the vertical variation of horizontal velocities in the depth-integrated models [35,36], but the vertical stratification has yet to be addressed. Lin and $\mathrm{Wu}[37,38]$ and Lin [39] examined thermally-driven flows over vegetated sloping bottoms with an idealized, linear, vertically-solved slice analytical model. It was reported that vegetation can significantly change the circulation pattern of the open water zone to a large extent. The studies also cautioned that the three-dimensional topography can greatly affect the circulation patterns. Using a three-dimensional (3D) hydrodynamic model with a hydrostatic pressure assumption [40,41], Coates and Folkard [29] pointed out that the mechanical drag of macrophytes plays a more important role than light attenuation. Recently, Kimura, et al. [20] investigated diurnal dynamics in a small shallow lake under wind sheltering effects and showed that maximum subsurface velocities were caused by weak stratification. Vilas, et al. [42] explored the impacts of littoral vegetation 
on spatial and temporal variation of temperature and dissolved oxygen in an urban lake. However, the impacts of submerged macrophytes on both the three-dimensional circulation pattern and thermal structure of small lakes under weak stratification conditions have not yet been reported.

The purpose of this paper is to investigate the effects of weak stratification and littoral submerged macrophytes on circulation and temperature dynamics in a small and shallow lake. Specifically, we conducted extensive field measurements to depict 3D circulation patterns and temperature structures using an acoustic instrument and multiple thermistor chains. The spatial distribution of littoral macrophytes was mapped using a GPS depth sounder. A spatially distributed array of wind sensors was also deployed over the lake area to capture wind sheltering. We employed a three-dimensional non-hydrostatic hydrodynamic model $[43,44]$ with a generic length scale (GLS) approach for the turbulence closure and vegetation-induced drag forces to simulate the effects of macrophytes on lake circulation patterns and thermal structures.

\section{Materials and Methods}

\subsection{Study Site}

Lake Wingra $\left(43^{\circ} 3^{\prime} \mathrm{N}, 89^{\circ} 26^{\prime} \mathrm{W}\right)$, located in Madison, Wisconsin, has a surface area of $1.3 \mathrm{~km}^{2}$ and a shoreline length of $5.9 \mathrm{~km}$ with mean and maximum water depths of $2.7 \mathrm{~m}$ and $4.3 \mathrm{~m}$ (excluding two small dredge holes), respectively. The largest fetch is approximately $2 \mathrm{~km}$ along the N-NE wind directions. Along the prevailing S and SW direction, the fetch ranges between 400 and $1000 \mathrm{~m}$. The riparian shoreline is mostly undeveloped, being largely surrounded by trees with heights typically $10 \mathrm{~m}$ above the water surface. The wind-sheltering due to these trees reduces the wind exposure of the lake [20]. Lake Wingra is a eutrophic drainage lake in a highly urbanized watershed [45,46]. During the summer, approximately $30 \%$ of the lake surface area is littoral habitat containing macrophytes of various species. Although the abundance of individual species might vary significantly from year to year $[47,48]$, long-term observations indicated that the most common macrophytes are submerged milfoils and the second most abundant plants are Ceratophyllum demersum, commonly knowns as coontails. Both species mostly spread offshore up to $2.0 \mathrm{~m}$ depth [49]. The spatial distribution of littoral macrophytes has generally remained constant over decades [47,48,50,51]. Figure 1 shows the spatial distribution of littoral-zone vegetation in Lake Wingra: https:/ / olw-lwrd.countyofdane.com/ Management/Aquatic-Plants / Aquatic-Plant-Management).

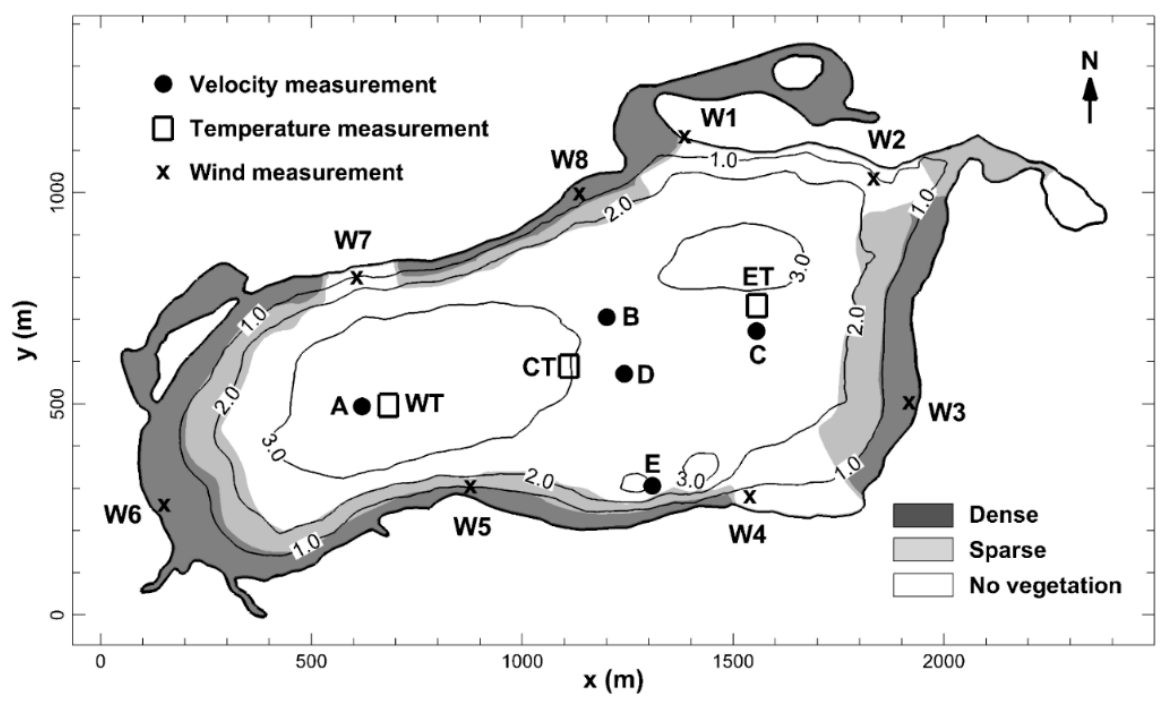

Figure 1. Lake Wingra bathymetry and the distribution of littoral-zone vegetation. Symbols $(\bullet, \square$ and $\times$ ) represent the locations of wind (W1-W8), water temperature (WT, CT, ET), and velocity profile measurements (A, B, C, D, and E), respectively. 


\subsection{Field Observations}

Field measurements were carried out in the summer and early fall of 2004. First, wind sensors (R.M. Young microvane with a 3-cup anemometer) were deployed at eight locations (Figure 1) to account for the spatial variation of the wind forcing. At each location, wind speed and direction were measured every 2 minutes at $1 \mathrm{~m}$ above the lake surface. The data were extrapolated to $10 \mathrm{~m}$ above the surface using the power law [52] to calculate wind forcing by the aerodynamic drag relationship [53]. The wind forcing over the whole lake was determined by bilinear interpolation of wind velocity components. Second, water temperature was measured using water temperature sensors, manufacture by Onset. Three thermistor chains were deployed at the west, center and east locations in the lake (Figure 1), with each chain consisting of six thermistors vertically spaced $0.5 \mathrm{~m}$ apart in the water column. At the top of each buoy attached to the thermistor chains, an Onset HOBO Thermocouple recorded the air temperature. All temperature data were recorded at 2-minute intervals. Cloud cover data were obtained from the database of National Climate Data Center (http: //cdo.ncdc.noaa.gov/ulcd/ULCD) located in Madison Dane County Regional Airport about (Truax Field), about $10 \mathrm{~km}$ northeast of Lake Wingra. Shortwave solar radiation and relative humidity data were available from the database of the rooftop monitoring station at the Atmospheric, Oceanic Space Science Building at University of Wisconsin-Madison (http:/ / rig.ssec.wisc.edu/), about $0.5 \mathrm{~km}$ north of Lake Wingra. Third, vertical profiles of water velocities were collected using a $600 \mathrm{kHz}$ RDI Workhorse Sentinel Acoustic Doppler Current Profiler (ADCP). The ADCP was mounted in a wood frame to achieve floating capability. For each weather event of interest, the ADCP was moved around the lake to measure the circulation pattern. The ADCP was floated at the surface and faced down, horizontally being secured by three cables each attached to an anchor. The data were recorded for at least $30 \mathrm{~min}$ at each location to eliminate possible frame oscillation and rotation caused by irregular surface waves. Vertical velocity profiles were separated into $10 \mathrm{~cm}$ interval bins with a sampling rate every $10 \mathrm{~s}$. Lastly, littoral macrophytes were mapped through extensive field surveys. Macrophyte density was determined by visually counting the number of individual vegetation stems in $1 \times 1 \mathrm{~m}^{2}$ plots throughout the littoral zone. The spatial distribution of littoral macrophytes was obtained by tracking the littoral boundary using a boat-mounted GPSmap 188 sounder, Garmin (International Inc., Olathe, KS, USA) with a horizontal spatial resolution of $25 \mathrm{~m}$.

\subsection{Hydrodynamic Model}

A three-dimensional, non-hydrostatic, free-surface, primitive-equations model [54] on the Cartesian Arakawa C grids [55] is used. The model employs the partial-cell approach [56,57] to discretize bathymetries. The model has been extensively evaluated for inviscid surface water waves $[57,58]$ and was further extended to include the generic length scale (GLS) approach for the turbulence closure and a drag force model to simulate flows through/over aquatic vegetation and thermal changes in a lake $[43,44]$. In contrast to the hydrostatic-pressure assumption that simplifies the vertical momentum equation to balance between the pressure gradient and gravity only [59], non-hydrostatic models that keep the full vertical momentum equation can be applicable for various processes like surface waves [60,61], flows over steep bottom topographies [62], evolution of nonlinear internal waves [63,64], and wind-driven upwelling over broader spatial and temporal scales [40,41].

In this paper, we briefly summarize the key features of the non-hydrostatic model. Detailed governing equations including the Reynolds-averaged continuity and momentum equations for the flow field, transport equation for temperature, and an equation of state that links water density to temperature can be found in the work of $\mathrm{Wu}$ and Yuan [54] and $\mathrm{Wu}$, et al. [43]. To simulate aquatic macrophytes, we assume macrophytes as clusters of rigid vertical cylinders with small diameters so that vegetation-induced drag forces are added in the $x, y$ and $z$ directions of the Cartesian coordinate, respectively.

$$
F_{x}=\frac{1}{2} \rho_{w} \lambda C_{D} u \sqrt{u^{2}+v^{2}}
$$




$$
\begin{gathered}
F_{y}=\frac{1}{2} \rho_{w} \lambda C_{D} v \sqrt{u^{2}+v^{2}} \\
F_{z}=0
\end{gathered}
$$

where $\rho_{w}$ is the water density, $\lambda$ is the total projected area of vegetation in a unit volume of mixture of water and vegetation $\left(\lambda=D_{v} N_{v}\right.$, with $D_{v}$ being the diameter of the single vegetation stand and $N_{v}$ is the total number of vegetation stands per $\mathrm{m}^{2}$ ); $C_{D}$ is the bulk drag coefficient, where $u$ and $v$ are horizontal velocity components in $x$ and $y$ coordinate directions, respectively; $F_{z}$ is zero by assuming the vegetation field as an anisotropic dissipative media $[37,65]$.

The horizontal and vertical viscosity terms originating from Reynolds-averaging are obtained through the turbulence closure model. The horizontal eddy viscosity is computed from the Smagorinsky sub-grid model [66] while the horizontal eddy diffusivity is assumed to be same as the horizontal eddy viscosity. The vertical eddy viscosity and eddy diffusivity are evaluated by accounting for the third-order moments and pressure correction terms in terms of stability functions that describe the competing effects of shear and stratification [67]. The turbulent kinetic energy and the turbulent length scale are determined from the GLS approach that solves two equations, one for the turbulent kinetic energy and one for a generic parameter for the turbulent length scale. The vegetation-induced wake production is

$$
W=F_{x} u+F_{y} v
$$

by assuming that the vegetation-induced drag-force terms in the momentum equations dominate the turbulent diffusive terms $[68,69]$. A detailed description of the GLS turbulence closure and its implementation to this model can be found in the work of $\mathrm{Wu}$, et al. [43]. To account for heat transfer at the lake bed, we follow Jin, et al. [70] to thermally couple sediment beds and the water column by

$$
K_{v} \frac{\partial T}{\partial z}=-C_{h b} \frac{\rho_{w} C_{p w}}{\rho_{b} C_{p b}} \sqrt{u_{b}^{2}+v_{b}^{2}}\left(T_{b}-T_{w}\right)
$$

where $K_{v}$ is the vertical eddy diffusivity; $C_{h b}$ is a dimensionless convective heat exchange coefficient; $\rho_{b}, C_{p b}$ and $T_{b}$ are the density, specific heat and temperate of the bottom sediments, respectively; $u_{b}$ and $v_{b}$ are the velocity components at the lake bed; and $T_{w}$ is the water temperature at the lake bed.

The governing equations of the non-hydrostatic model are solved by an efficient implicit method [58]. The turbulence quantities are updated after the mean-flow quantities and the temperature equation is solved lastly at each time level. The transport equations are solved using a simple forward scheme in time, which treats the advection horizontal diffusion terms explicitly and the vertical diffusion fully implicitly. We use the 1D Superbee total maximum variation scheme [71] to compute the advection term in the $x, y$ and $z$ directions, and the standard central scheme is used for horizontal and vertical diffusions. The model has been extensively validated against many free-surface flow problems $[43,44,54,57]$. Overall, the non-hydrostatic model is capable of simulating lake temperature stratification and vegetation effects on flow motions of various kinds such as linear and nonlinear waves from deep to shallow water [43,58].

\subsection{Model Setup}

The model is setup with a horizontal grid size of $50 \mathrm{~m}$, which is determined by grid-refinement tests from $100 \mathrm{~m}, 50 \mathrm{~m}$ and $25 \mathrm{~m}$ to yield grid-independent results of the circulation pattern and thermal structure. A vertical resolution of $0.25 \mathrm{~m}$ is used to obtain the velocity profile. The total grid number is $47 \times 29 \times 15$, in the $x-, y$ - and z-directions, respectively. According to the field observations on mapping macrophytes, we classify the lake surface into three areas based upon the observed vegetation density as a dense, sparse colony with mixed species and no vegetation. Specifically, the area with dense vegetation is characterized with $\lambda=10 \mathrm{~m}^{-1}$ (1000 macrophyte stands per $1 \mathrm{~m}^{2}$ with diameter of $0.01 \mathrm{~m}$ ), while $\lambda=1 \mathrm{~m}^{-1}$ (100 macrophyte stands per $1 \mathrm{~m}^{2}$ with diameter of $0.01 \mathrm{~m}$ ) is used to classify the sparse area. Figure 1 shows the spatial pattern of macrophyte distribution from the 2004 
survey and the distribution generally agrees with patterns obtained in 1991 and 1992 surveys (i.e., Figure 4 in Reference [48]). At last, the bulk drag coefficient of macrophytes is chosen to be 1.13 based on Garcia, et al. [65].

The hydrodynamic model is driven by meteorological data including solar radiation, air temperature, wind speed and direction, as shown in Figure 2. The wind stress at the water surface is calculated over each cell via an aerodynamic drag relationship with a wind speed-dependent drag coefficient and based on an interpolated wind field at $10 \mathrm{~m}$ height [53,72]. The dense forest around the shoreline can produce a sheltered zone over the lake surface, which can result in a relatively inhomogeneous wind field [20]. It was revealed that the affected lake surface ratio is between $10 \%$ to $20 \%$, consistent with the estimation of $12-18 \%$ based on the formula of Markfort, et al. [73]. A spatial bilinear interpolation for wind stress is employed to address different forest densities around the lake. Since the temperature transport equation is driven by meteorological data including turbulent heat fluxes, longwave radiation and solar radiation, we calculate evaporative (latent) and sensible turbulent heat fluxes using wind speed, air temperature and relative humidity via bulk aerodynamic methods [20]. Net longwave radiation is calculated based on air temperature, surface water temperature and cloud cover data [20]. Based upon Secchi depth measurements and sensitivity analysis, a shortwave solar radiation attenuation coefficient of $1.0 \mathrm{~m}^{-1}$ is appropriate for the period of simulations [74]. The bottom friction coefficient is selected as 0.002 [20,72]. A time step of $60 \mathrm{~s}$ is chosen, yielding a ratio of simulation time to real time of about 1:15. The model is initialized on Day 253 at midnight with a zero velocity over the lake and a temperature measured at the central location (see Figure 1) at that time. The simulation lasts for 8 days until Day 261, and the first $24 \mathrm{~h}$ are used to spin up the model. Prior to the simulation, the model was carefully calibrated with field measurements and the water velocities and temperature fields predicted by the model are in good agreement with field observations within $10 \%$ errors.

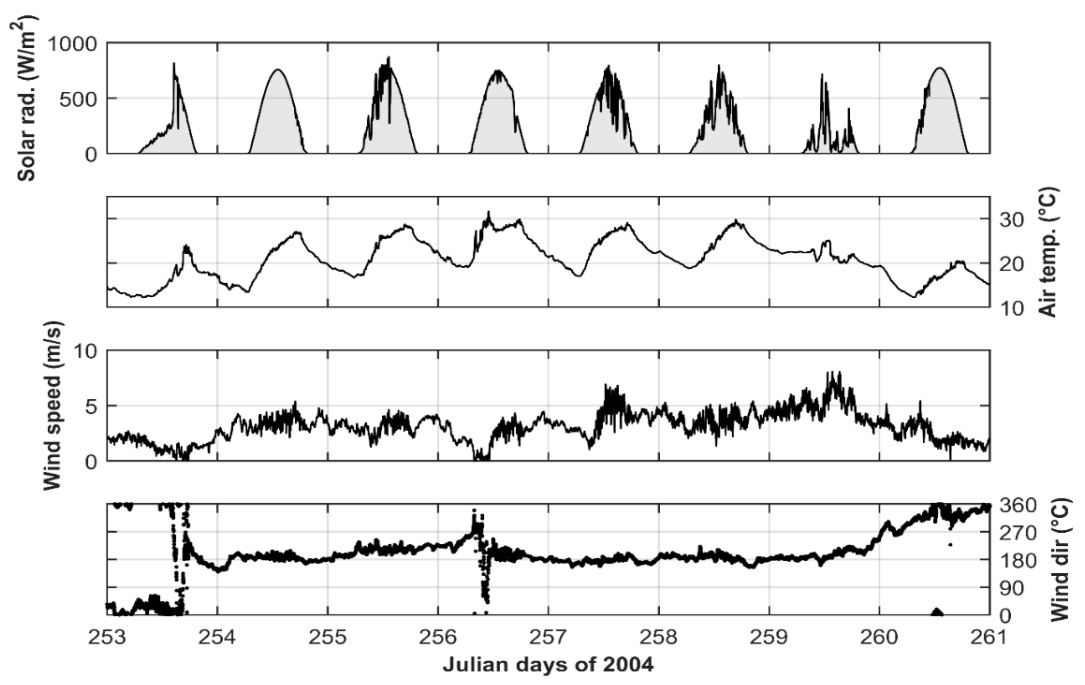

Figure 2. Measured meteorological data during 253-261 Julian day. Solar radiation was measured at the Atmospheric and Ocean Space Science Rooftop station, wind speed and direction were measured at station W8 in Figure 1, while air temperature was measured at central location CT in Figure 1.

\section{Results and Discussion}

\subsection{Temperature Structures}

The highly dynamic thermal structure of Lake Wingra in the summer is discussed here. Figure 3 shows the time series of the measured water temperature profile at the central location during September 10 (Day 254) to September 18 (Day 261). Depending upon wind shear and heat transfer at the lake surface, Lake Wingra can shift from stratified periods to well-mixed regimes on a daily or even 
hourly basis. The weak stratification (with bottom-to-surface temperature differential of order $1^{\circ} \mathrm{C}$ ) occurred on Days 254 and 255, while it was intensified on Day 256 under very calm wind conditions (see Figure 2). The bottom-to-surface temperature difference reached $2.5^{\circ} \mathrm{C}$ around $6 \mathrm{pm}$. Afterwards, the stratification was weakened but not destroyed by the nocturnal negative surface buoyancy heat flux. On Day 257, stratification decreased for a few hours due to wind-induced mixing. As wind became moderate, stratification tended to re-develop. The combined effects of a strong wind, a reduced solar radiation and a cooling front destroyed the stratification (see Figure 2), leading to well-mixing on Day 259. Overall, water temperature exhibited an immediate response to surface heat fluxes with evident diurnal cycling, except on Day 259 when significant air cooling and cloud cover weakened the diurnal temperature structure.
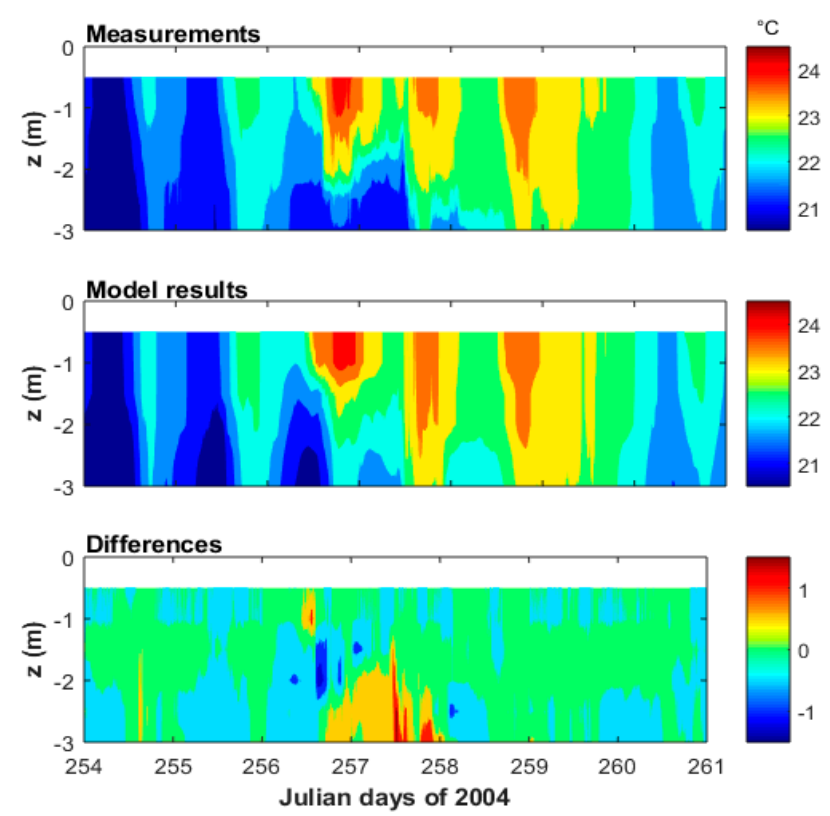

Figure 3. Measured and modelled water temperature time series at different depths at the central (CT) location. The lines with double arrows indicate the period of velocity measurements using ADCP.

The comparison between the time series of modeled and measured water temperature profiles at the central location is also shown in Figure 3. Overall, the simulation results predicted by the non-hydrostatic model incorporating vegetation effects agree well with field observations over a 7-day period (from Day 254 to Day 261) with differences less than $0.5{ }^{\circ} \mathrm{C}$ overall except for the bottom temperature on Day 257. The model faithfully reproduces the weak stratification on Days 256 and 257 and mixing on Day 259. The model also captures the weak stratification occurring on other days. On Day 258, that is at the middle of a 3-day southerly wind event, the model reasonably resolves weak stratification, providing the base for further examining circulation patterns in the next section. Two points are worthwhile discussing here. First, at depths close to the lake bottom (i.e., 2.5 and $3.0 \mathrm{~m}$ below the water surface), the predicted temperatures during the day generally match well but slightly mismatch during the night time. In the past, the zero bottom heat flux, typically employed in simulations of relatively deep, strongly stratified lakes $[75,76]$, can lead to an over prediction of bottom water temperature. In this paper, the use of Equation (5), bottom heat flux exchange with $C_{p b}=0.001$ [77] and $\rho_{b}$ ranging from $1010 \mathrm{~kg} / \mathrm{m}^{3}$ for mud to $1800 \mathrm{~kg} / \mathrm{m}^{3}$ for sand, enables the model to reliably capture weak stratification. Overall, both field measurements and modeling results indicate that the heat exchange at the water-lakebed interface can play an important role in maintaining weak stratification. Second, the model, however, does not fully resolve the high-frequency oscillations of small-scale internal waves [78,79], since the model was run under a spatial resolution of $50 \mathrm{~m}$, which is unlikely to simulate complex sub-grid scale oscillations [80]. 


\subsection{Velocity Prfoiles}

Figure 4 shows the comparison of averaged water velocity profiles between model results and field measurements with error bars consisting of standard deviations and instrument errors over an ensemble average period of $30 \mathrm{~min}$ for each of the five locations (see Figure 1) between $12 \mathrm{pm}$ to $5 \mathrm{pm}$ during Day 258. Both wind magnitudes and directions during the measurement period were relatively steady. The lake was under a southerly wind with an average speed of $4 \mathrm{~m} / \mathrm{s}$. Generally, the velocity profiles at the pelagic A, B, C, and D locations dominated northward velocities at the water surface along the direction of the wind and strong return southern velocities at about 1.5 to $2.0 \mathrm{~m}$ below the surface. The magnitude of return velocities was comparable to surface currents, both being up to $5 \mathrm{~cm} / \mathrm{s}$. The profile of northward velocity was marked by a strong shear. The eastward velocity, on the other hand, had a smaller magnitude with a profile of almost zero velocity. Overall, the modeled results are better than those predicted by a hydrostatic hydrodynamic model [20], suggesting that a non-hydrostatic model is capable of predicting velocity profiles under a weak stratification condition. At location E, close to the littoral zone, profiles of both northward and eastward velocities were different from those at the pelagic locations, indicating that littoral macrophytes somehow could complicate circulation patterns. A comparison between model results and field measurements shows a good agreement in the eastward direction but apparent discrepancy along the northward direction. Specifically, the modeled surface velocity follows the wind direction but field measurements show an opposite direction. This mismatch may be attributed to the velocity change due to patches of small-scale dense submerged macrophytes [81]. Another possibility is the complicated flow profiles due to horizontal large eddies at the boundary of the littoral zone [81-83]. To resolve the flow pattern at the littoral zone boundary, an anisotropic turbulence model in combination with a fine enough grid resolution $[84,85]$ is suggested for future study.
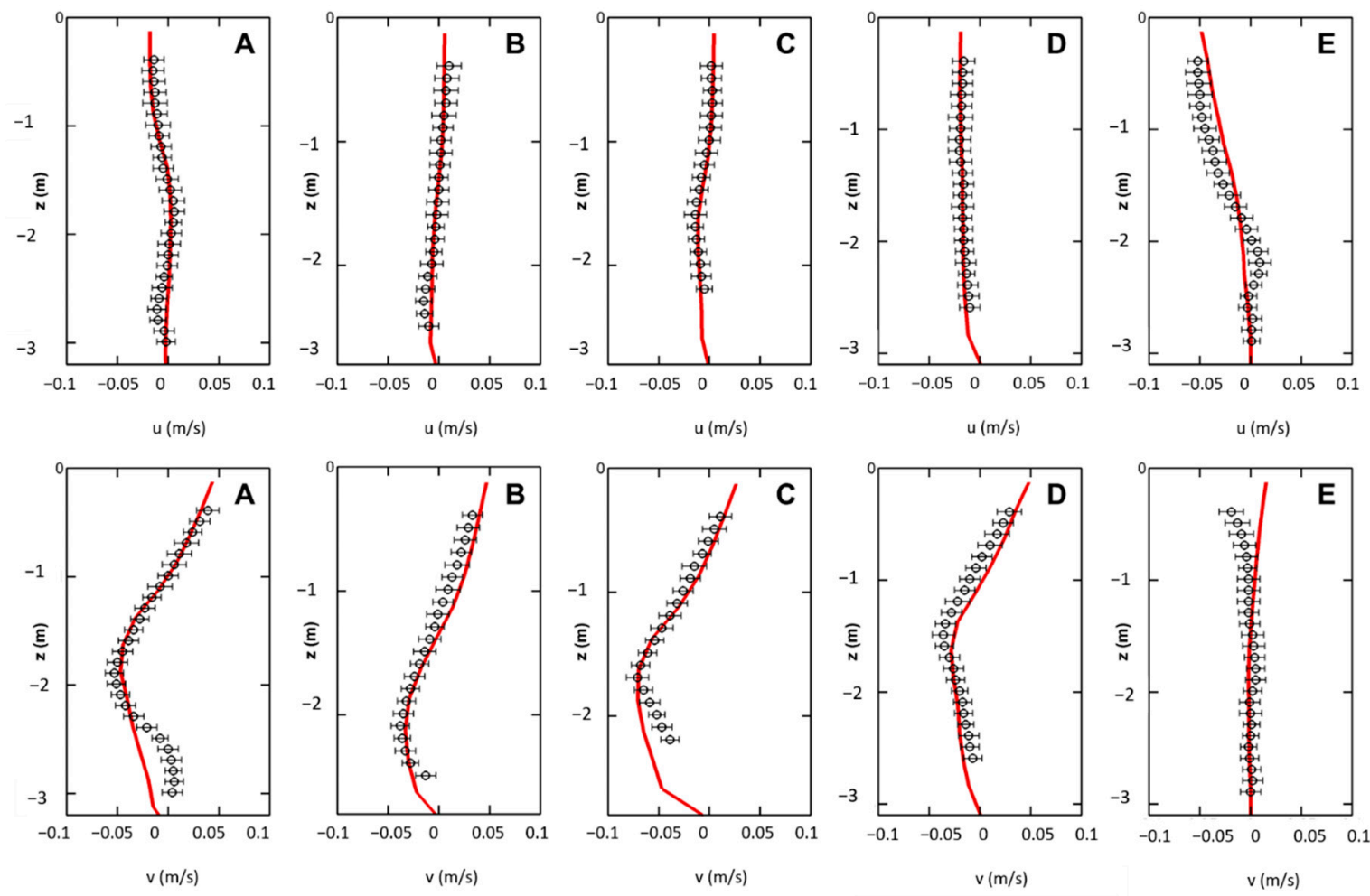

Figure 4. Comparison of eastward $(u)$ and northward $(v)$ velocity component profiles on the upper and lower panels, respectively, between modelled results (solid lines) and field observations (circles) with error bars at the five velocity measurement locations (see A, B, C, D, and E in Figure 1). Model results are averaged over the 5-h measurement interval, while observations represent half hour averages. 


\subsection{Effects of Macrophytes}

The effects of macrophytes on three-dimensional circulation patterns and velocity profiles are examined by comparing two modeling scenarios with and without littoral macrophytes. Figure 5 shows the horizontal circulation patterns of Lake Wingra. At the water surface, the contour line is plotted to delineate the area where velocity magnitude changed at least $50 \%$. Inside the littoral zone, macrophytes greatly retard the mean flow and velocity magnitudes are remarkable decreased. In the pelagic area and far away from the littoral macrophyte zone, the flow patterns with and without macrophytes are similar. Nevertheless, velocity magnitudes in general are reduced to a large extent. Between the littoral macrophyte zone and the pelagic area, the flow patterns changed significantly, especially in the northwest shoreline. At $2 \mathrm{~m}$ below the water surface, the circulation patterns, as shown in Figure 5, are similar over the whole lake area, due to sparse littoral macrophytes at that lake depth. Figure 6 compares the modeled and measured profiles of total horizontal velocities at two locations. At location B (see Figure 1), which is located in the pelagic area of the lake, the model with littoral macrophytes shows minor effects on velocity profiles. Similar results are also seen at locations A, C and D far away from the littoral zone and are not shown here for brevity. In general, it is found that a two-layer structure profile with one maximum velocity at the water surface and the other one at the mid-depth due to weak stratification, consistent with the results reported by others [20-22]. The velocities of the upper layer are approximately parallel with the wind direction. In contrast, the velocities of the lower layer have an opposite direction due to the pressure gradient that is caused by the water level set up on the leeward shore. Velocity gradients along the depth are governed by the stratification that is affected by turbulence, which will be discussed later. At location E (see Figure 1) in the littoral zone of the lake, the effects of macrophytes become evident. The model without macrophytes cannot match the measured velocity profile. In contrast, the model with macrophytes reliably captures the measured total horizontal velocity profile that has the maximum at the surface, a steeper decrease until $2.0 \mathrm{~m}$ depth and another slight decrease to the lake bottom. In short, the non-hydrostatic model with a generic length scale (GLS) approach for the turbulence closure and drag forces induced by macrophytes faithfully depicts the effects of macrophytes on three-dimensional circulation patterns and velocity profiles in Lake Wingra.


Figure 5. Modelled circulation patterns with and without the littoral macrophytes at the surface and at $2 \mathrm{~m}$ below the surface. The solid contour lines delineate the area where velocity magnitude changed at least with $50 \%$ by the inclusion of macrophytes. The circulation field represents the same 5 -h averages as Figure 4. 

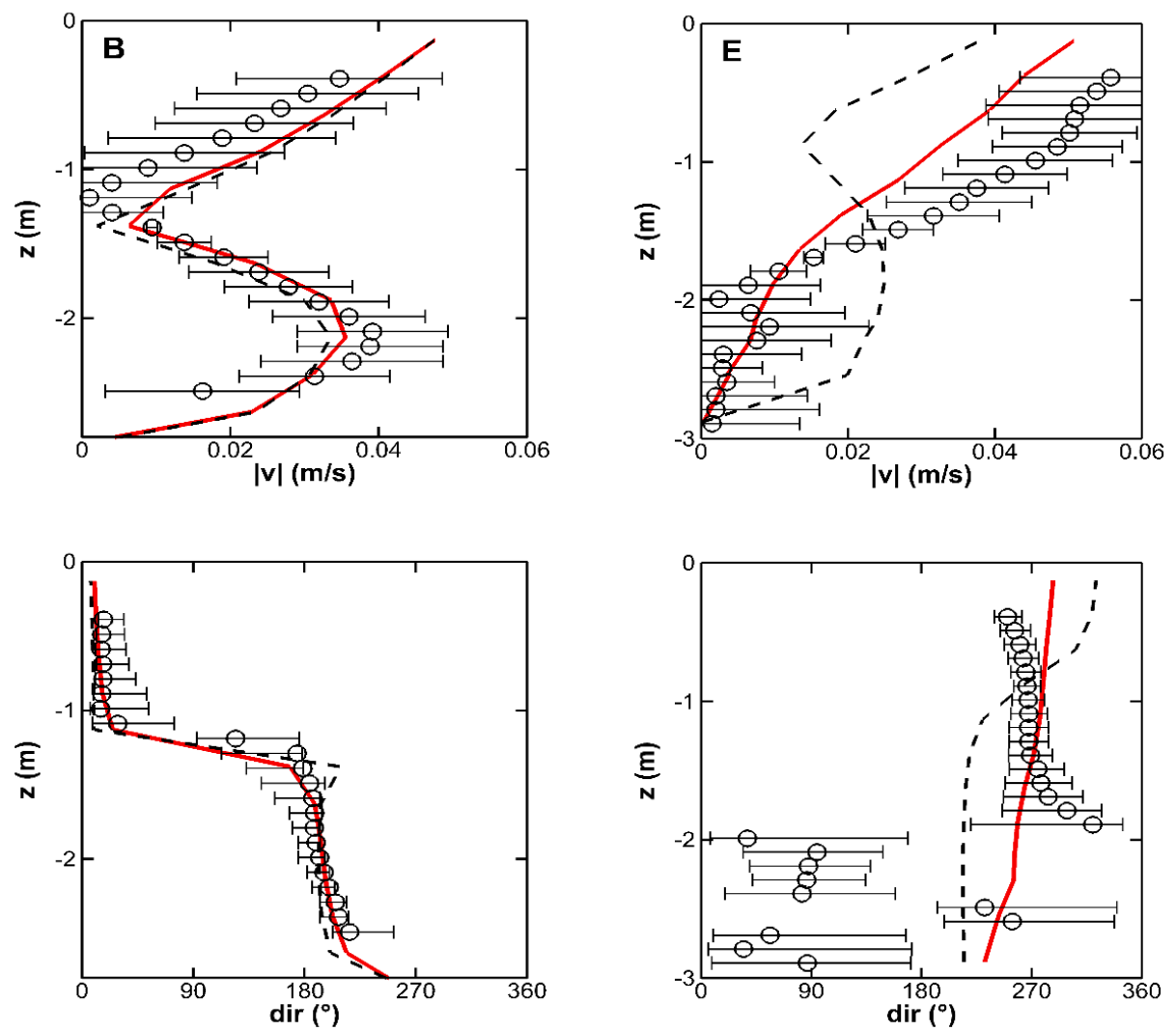

Figure 6. Comparison of velocity profiles between field observations (circles) with error bars and modelled results with (solid red lines) and without (black dashed lines) littoral macrophytes at location $\mathbf{B}$ in the pelagic area and location $\mathbf{E}$ in the littoral zone. The upper panel shows velocity magnitudes and the lower panel shows directions.

The effects of macrophytes on thermal structures are also examined by comparing two modeling scenarios with and without littoral macrophytes. Figure 7 shows the surface temperature field at $4 \mathrm{pm}$ on Day 258. The model scenario without macrophytes shows that the water temperature on the upwind side of Lake Wingra is lower than that on the downwind side, as large as $1^{\circ} \mathrm{C}$ difference. The surface currents driven by the southerly wind during this period convey the warm water to the leeward shore where vertical currents bring them to deeper regions as return flows. The model scenario with littoral macrophytes appears to reduce the temperature difference to $0.5^{\circ} \mathrm{C}$, suggesting that the littoral macrophytes can dampen the horizontal temperature difference by altering circulating patterns, net heat fluxes, or the combination of both (see Figure 5). We further compare the modelled temperature and velocity structures in Figure 8. The upper panel shows the temperature field and velocity circulation pattern along the cross section at $x=1250 \mathrm{~m}$ in Figure 7 following the wind direction. Overall, the temperature structures are similar but macrophytes appear to retard the horizontal velocity to enhance stratification inside the littoral zone at the north shore, as shown in the top right of the figures. The model scenario with macrophytes suggests that the buoyancy force due to the stable stratification interacts with the downward vertical velocity to develop stronger stratification. The lower panel shows the temperature field and circulation pattern along the cross section $y=500 \mathrm{~m}$ in Figure 7 perpendicular to the wind direction. On the eastern part of Lake Wingra, the model scenario with macrophytes shows the bottom temperature which, in comparison with that without macrophytes, decreases to develop a stronger stratification inside the littoral zone and even extends to the pelagic zone. The overall surface-to-bottom temperature difference increases by about $20 \%$, which is caused by the reduction of wind mixing due to the vegetation-induced drag force. Previous studies suggested that submerged macrophytes can enhance daytime stratification and reduce the mixed layer depth by increased solar radiation attenuation and reduced wind mixing $[32,33,72]$. In this paper, it is found 
that the three-dimensional temperature structures in a small and shallow lake can be affected by velocity retardation and vertical mixing reduction due to littoral macrophytes, which have not yet been reported in the literature before.
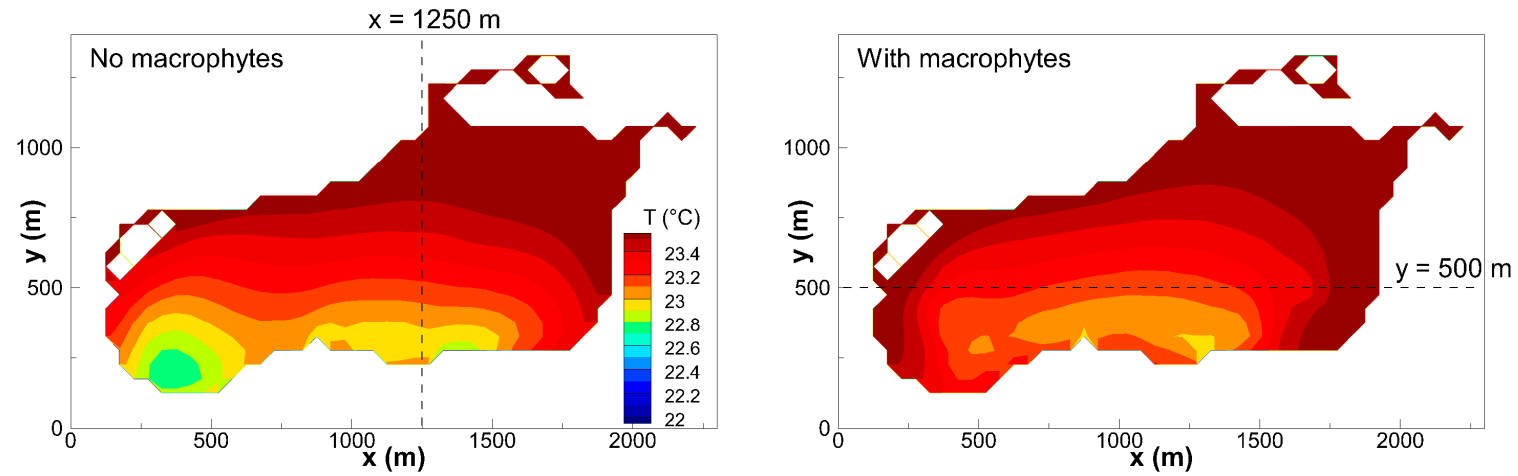

Figure 7. Modelled surface temperature fields without and with littoral macrophytes.
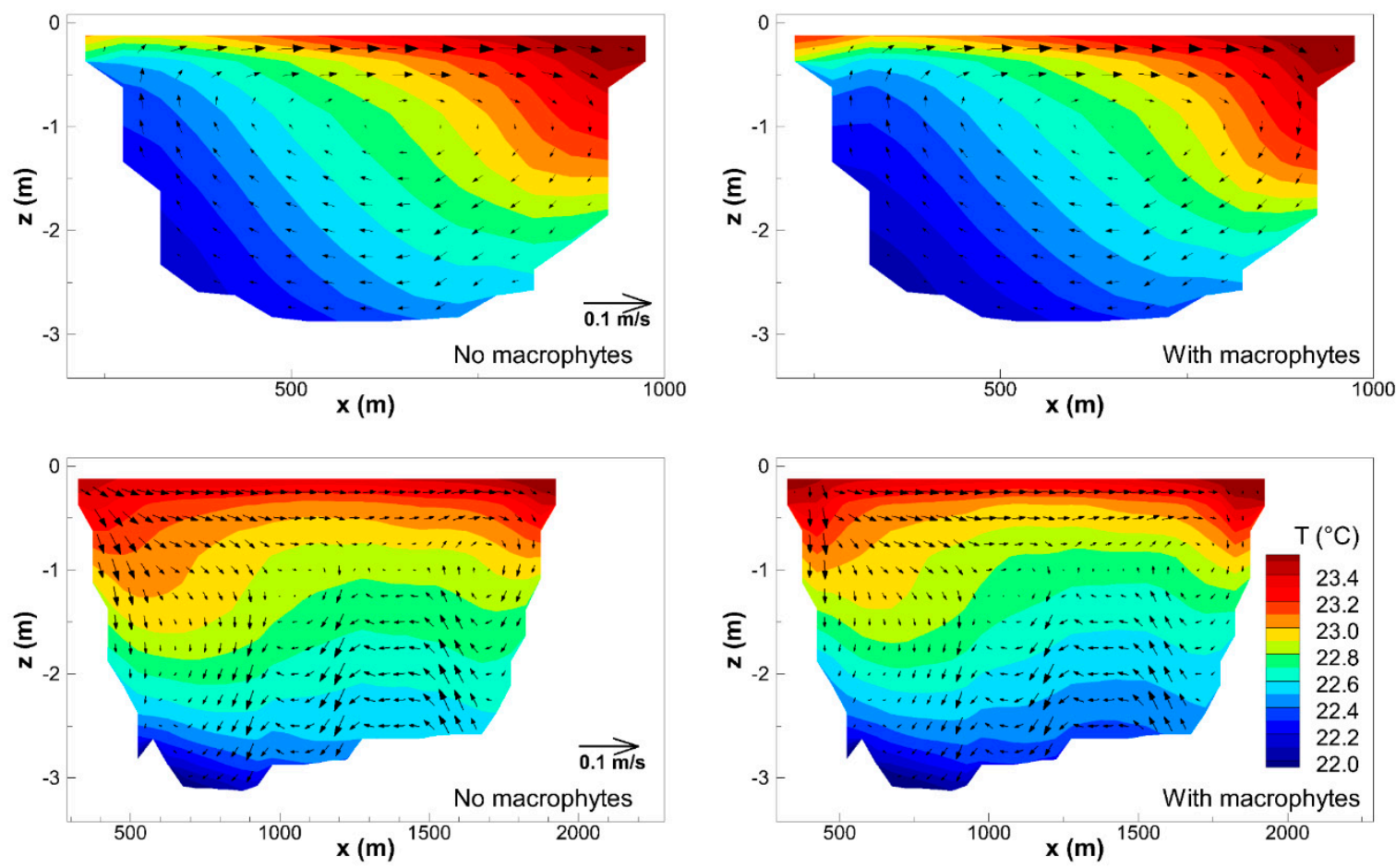

Figure 8. Modelled temperature fields and velocity circulation patterns of a cross section following (upper panel), and perpendicular to (lower panel), the wind direction without and with littoral macrophytes. The upper panel is the cross section along $x=1250 \mathrm{~m}$ and the lower panel is the cross section along $y=500 \mathrm{~m}$, which are marked by the dashed lines in Figure 7.

\subsection{Effects of Weak Stratification}

The effects of weak stratification on velocity profiles are examined by comparing two modeling scenarios with and without considering the temperature transport equation, i.e., baroclinic and barotropic scenarios, respectively. All parameters in the model are kept unchanged. Figure 9 shows the modeled total horizontal velocity at location B. Under the barotropic or no weak stratification scenario, the velocity magnitude is relatively smaller (see dashed line in Figure 9). The velocity profile has large gradients near the water surface and the lake bed, but is constant at the mid-layer, which is totally different from the two-layer velocity profile under the baroclinic scenario. In other words, a smooth and log layer velocity profile under the barotropic scenario is replaced by the two-layer 
velocity profile under the baroclinic scenario, suggesting the importance of weak stratification in affecting the velocity profile in the pelagic zone. Furthermore, current velocities without considering the effects of weak stratification are significantly under predicted. Figure 9 shows the profiles of eddy turbulent viscosity at location B for the two scenarios. The eddy turbulent viscosity under the baroclinic scenario obtained by the turbulence closure model is suppressed by temperature stratification, yielding much smaller magnitudes in comparison to those of the barotropic scenario. Under identical wind forcing, a larger velocity gradient is required in the presence of stratification to produce the similar or equivalent shear stress (note that the shear stress is equal to the product of eddy viscosity and velocity shear). Interestingly, the turbulence-induced viscous effect on velocity profiles is also recognized by References [86,87] in tidal currents, although both studies did not focus on weak stratification. Overall, the two (baroclinic and barotropic) modeling scenarios indicate that weak stratification is of fundamental importance to velocity profiles in a small and shallow lake.
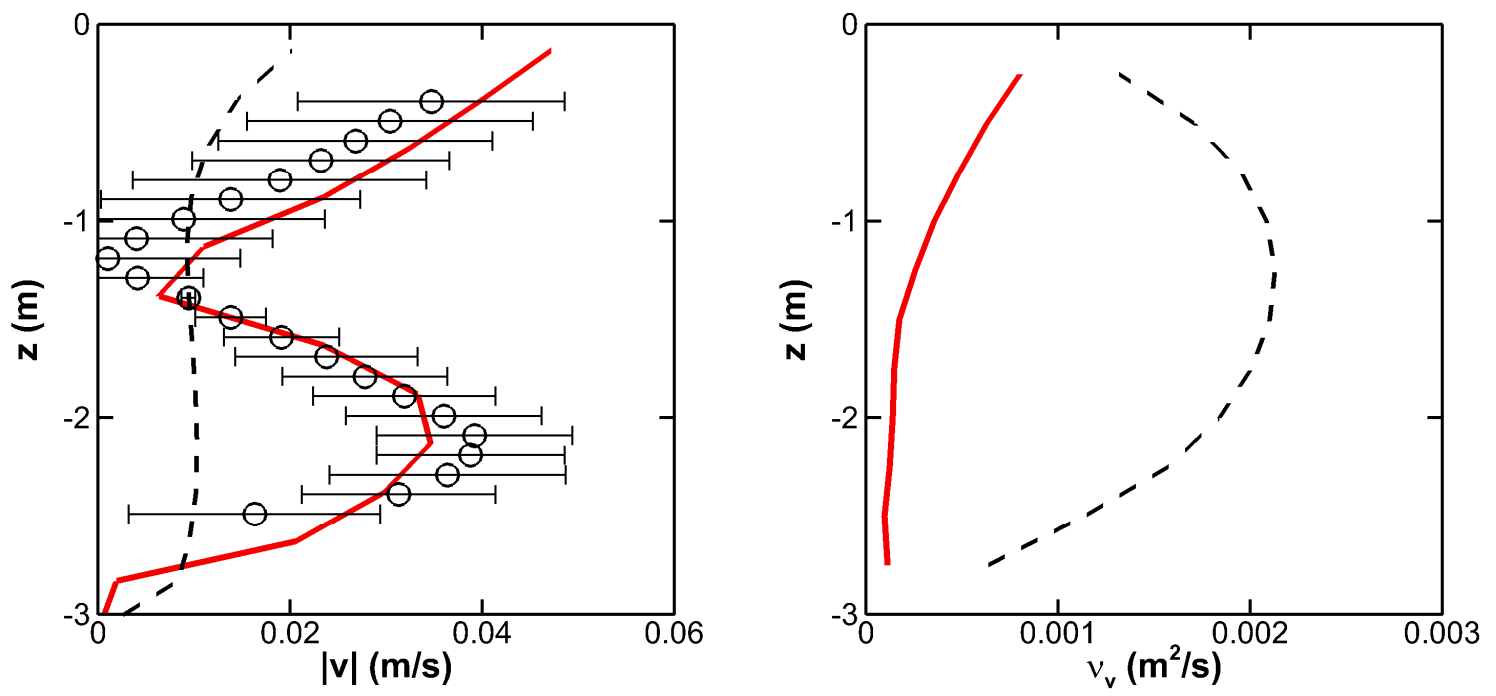

Figure 9. Model results of total horizontal velocity $|\mathrm{v}|$ and eddy viscosity $v_{v}$ profiles with (red solid line) and without (black dashed line) weak stratification effects. Measured total horizontal velocity profiles are denoted as circles with error bars.

\section{Summary and Conclusions}

This paper presents a modeling study that aims to address the effects of littoral submerged macrophytes and weak stratification on temperature and circulation dynamics of a small and shallow lake under mild to moderate wind conditions during the summer time. Extensive field measurements including macrophyte mapping and spatially distributed arrays of water velocity, water temperature and wind fields were conducted. A three-dimensional non-hydrostatic model with a generic length scale (GLS) approach for turbulence closure and vegetation-induced drag forces was incorporated to reveal the effects of macrophytes on temporal and spatial dynamics of thermal structures and circulation patterns. Results show that diurnal dynamics of weak stratification with a temperature differential of $1-3{ }^{\circ} \mathrm{C}$ over a $3 \mathrm{~m}$ depth is sensitively subjected to wind speeds and net heat fluxes from the water surface and lake bottom. Based on the model scenarios and field measurements, the effects of macrophytes on velocity profiles and circulation patterns are apparent. In the pelagic area, the circulation patterns with and without macrophytes are similar but inside the littoral zone macrophytes greatly retard the mean flow. In contrast, littoral macrophytes significantly change the two-layer structure profile with the maximum velocity at both the water surface and the mid-depth under weak stratification to a profile consisting of only one maximum velocity at the surface with two different decreasing rates to the lake bottom. Furthermore, littoral macrophytes retard the horizontal temperature difference by altering circulating patterns, net heat fluxes, or the combination of both. 
A stronger temperature stratification is also formed due to vertical mixing reduction, which arises from retarding mean flows. The role of weak stratification on velocity profiles in Lake Wingra is also elucidated through the comparison of horizontal velocity profiles and turbulent eddy viscosities. The two-layer velocity profile is captured by the baroclinic model scenario, in contrast to the monotonic velocity profile with smaller magnitudes obtained from the barotropic model scenario. Magnitudes of eddy turbulent viscosity under the baroclinic scenario are much smaller due to the suppression by temperature stratification.

Small and shallow lakes have been regularly reckoned as fully mixed homogeneous systems in the past. While a great deal of progress in understanding the role of weak thermal stratification with surface-to-bottom temperature differentials of $1-4{ }^{\circ} \mathrm{C}$ has been made [5,16-22], future studies are suggested to address the effects of diverse macrophytes commonly occupying a large portion of water on temperature and circulation dynamics in shallow lakes. The development of models that account for various vegetation types, such as floating-leaved and free-floating plants [88], are highly desired to represent their impact on drag and light attenuation conditions. This type of study requires high-fidelity hydrodynamic modeling in a real lake environment, in which flow motions in horizontal and vertical dimensions might be equally significant. In this context, 3D non-hydrostatic modeling is highly recommended.

Author Contributions: Conceptualization and Methodology, C.H.W. and P.T.; Software (non-hydrostatic model), C.H.W.; Validation, Formal Analysis, Investigation, T.P and C.H.W.; Resources and data curation, C.H.W.; Writing-Original Draft Preparation, P.T. and C.H.W.; Writing-Review and Editing, C.H.W., P.T.; Visualization, P.T.; Supervision, C.H.W.; Project Administration, C.H.W.; Funding acquisition, C.H.W. and P.T.

Funding: Funding support for the first author was provided in part by the Fulbright Scholar Program, North Temperate Lakes Long Term Ecological Research Project (NSF 0217533) and Anna Grant Birge Award, Dane County Land and Water Resources Department, and College of Engineering at University of Wisconsin-Madison (UW-Madison).

Acknowledgments: We would like to thank Richard (Dick) Lathrop at Wisconsin Department of Natural Resources and Stephen Carpenter at Center of Limnology for providing valuable insight of water quality issues of Lake Wingra and their support on this research subject. The authors also would like to acknowledge Hengliang Yuan and Nobuaki Kimura for conducting field measurements and performing hydrodynamic modelling of Lake Wingra. Last but not least, encouragements from John A. Hoopes and Kenneth Potter, emeritus professors in Civil and Environmental Engineering Department at UW-Madison on the second author are highly appreciated.

Conflicts of Interest: The authors declare no conflict of interest.

\section{References}

1. George, D.G.; Heaney, S.I. Factors influencing the spatial distribution of phytoplankton in a small productive Lake. J. Ecol. 1978, 66, 133. [CrossRef]

2. Schindler, D.W.; Mills, K.H.; Malley, D.F.; Findlay, D.L.; Shearer, J.A.; Davies, I.J.; Turner, M.A.; Linsey, G.A.; Cruikshank, D.R. Long-Term Ecosystem Stress: The effects of years of experimental acidification on a small lake. Science 1985, 228, 1395-1401. [CrossRef] [PubMed]

3. Hilton, J.; Lishman, J.P.; Allen, P.V. The dominant processes of sediment distribution and focusing in a small, eutrophic, monomictic lake. Limnol. Oceanogr. 1986, 31, 125-133. [CrossRef]

4. Fee, E.J.; Shearer, J.A.; DeBruyn, E.R.; Schindler, E.U. Effects of lake size on phytoplankton photosynthesis. Can. J. Fish. Aquat. Sci. 1992, 49, 2445-2459. [CrossRef]

5. Carlsson, P.; Caron, D.A. Seasonal variation of phosphorus limitation of bacterial growth in a small lake. Limnol. Oceanogr. 2001, 46, 108-120. [CrossRef]

6. Cole, J.J.; Carpenter, S.R.; Kitchell, J.F.; Pace, M.L. Pathways of organic carbon utilization in small lakes: Results from a whole-lake $13 \mathrm{C}$ addition and coupled model. Limnol. Oceanogr. 2002, 47, 1664-1675. [CrossRef]

7. Phillips, G.L. Eutrophication of shallow temperate lakes. In The Lakes Handbook; Blackwell Science Ltd.: Oxford, UK, 2005; Volume 2, pp. 261-278.

8. Bengtsson, L.; Hellström, T. Wind-induced resuspension in a small shallow lake. Hydrobiologia 1992, 241, 163-172. [CrossRef] 
9. Lacroix, G.; Lescher-Moutou, F. Spatial patterns of planktonic microcrustaceans in a small shallow lake. Hydrobiologia 1995, 300-301, 205-217. [CrossRef]

10. Scheffer, M. Ecology of Shallow Lakes, 1st ed.; Springer US: New York, NY, USA, 1998; ISBN 978-0-412-74920-9.

11. Blindow, I.; Hargeby, A.; Meyercordt, J.; Schubert, H. Primary production in two shallow lakes with contrasting plant form dominance: A paradox of enrichment? Limnol. Oceanogr. 2006, 51, 2711-2721. [CrossRef]

12. Barko, J.W.; Gunnison, D.; Carpenter, S.R. Sediment interactions with submersed macrophyte growth and community dynamics. Aquat. Bot. 1991, 41, 41-65. [CrossRef]

13. Dixon, K.R.; Florian, J.D. Modeling mobility and effects of contaminants in wetlands. Environ. Toxicol. Chem. 1993, 12, 2281-2292. [CrossRef]

14. Tanino, Y. Water exchange between littoral zone and open lake water. Encycl. Lakes Reserv. Encycl. Earth Sci. Ser. 2012, 869-872.

15. Fischer, H.B.; List, E.J.; Koh, R.C.Y.; Imberger, J.; Brooks, N.H. Mixing in Inland and Coastal Waters; Academic Press, Elsevier: London, UK, 2013; ISBN 9780080511771.

16. Pernica, P.; Wells, M. Frequency of episodic stratification in the near surface of Lake Opeongo and other small lakes. Water Qual. Res. J. Can. 2012, 47, 227. [CrossRef]

17. McEnroe, N.A.; Buttle, J.M.; Marsalek, J.; Pick, F.R.; Xenopoulos, M.A.; Frost, P.C. Thermal and chemical stratification of urban ponds: Are they 'completely mixed reactors'? Urban Ecosyst. 2013, 16, 327-339. [CrossRef]

18. Pernica, P. Implications of Periodic Weak Thermal Stratification in the Epilimnion of Lake Opeongo; University of Toronto: Toronto, ON, Canada, 2014.

19. Andersen, M.R.; Sand-Jensen, K.; Iestyn Woolway, R.; Jones, I.D. Profound daily vertical stratification and mixing in a small, shallow, wind-exposed lake with submerged macrophytes. Aquat. Sci. 2017, 79, 395-406. [CrossRef]

20. Kimura, N.; Wu, C.H.; Hoopes, J.A.; Tai, A. Diurnal dynamics in a small shallow lake under spatially nonuniform wind and weak Stratification. J. Hydraul. Eng. 2016, 142, 04016047. [CrossRef]

21. Torma, P.; Krámer, T. Modeling the effect of waves on the diurnal temperature stratification of a shallow lake. Period. Polytech. Civ. Eng. 2016, 61, 165-175. [CrossRef]

22. Condie, S.A.; Webster, I.T. Stratification and circulation in a shallow turbid waterbody. Environ. Fluid Mech. 2002, 2, 177-196. [CrossRef]

23. Podsetchine, V.; Schernewski, G. The influence of spatial wind inhomogeneity on flow patterns in a small lake. Water Res. 1999, 33, 3348-3356. [CrossRef]

24. Honti, M.; Istvánovics, V.; Staehr, P.A.; Brighenti, L.S.; Zhu, M.; Zhu, G. Robust estimation of lake metabolism by coupling high frequency dissolved oxygen and chlorophyll fluorescence data in a Bayesian framework. Int. Waters 2016, 6, 608-621. [CrossRef]

25. Nepf, H.M. Drag, turbulence, and diffusion in flow through emergent vegetation. Water Resour. Res. 1999, 35, 479-489. [CrossRef]

26. Darby, S.E. Effect of riparian vegetation on flow resistance and flood potential. J. Hydraul. Eng. 1999, 125, 443-454. [CrossRef]

27. Wilson, C.A.M.E.; Stoesser, T.; Bates, P.D.; Pinzen, A.B. Open channel flow through different forms of submerged flexible vegetation. J. Hydraul. Eng. 2003, 129, 847-853. [CrossRef]

28. Mendez, F.J.; Losada, I.J. An empirical model to estimate the propagation of random breaking and nonbreaking waves over vegetation fields. Coast. Eng. 2004, 51, 103-118. [CrossRef]

29. Coates, M.J.; Folkard, A.M. The effects of littoral zone vegetation on turbulent mixing in lakes. Ecol. Modell. 2009, 220, 2714-2726. [CrossRef]

30. Abt, S.R.; Clary, W.P.; Thornton, C.I. Sediment deposition and entrapment in vegetated streambeds. J. Irrig. Drain. Eng. 1994, 120, 1098-1111. [CrossRef]

31. Thorne, C.R. Effects of vegetation on riverbank erosion and stability. In Vegetation and Erosion: Processes and Environments; J. Wiley: Chichester, UK, 1990; pp. 128-144.

32. Herb, W.R.; Stefan, H.G. Dynamics of vertical mixing in a shallow lake with submersed macrophytes. Water Resour. Res. 2005, 41, 1-14. [CrossRef]

33. Herb, W.R.; Stefan, H.G. Model for wind-driven vertical mixing in a shallow lake with submersed Macrophytes. J. Hydraul. Eng. 2005, 131, 488-496. [CrossRef] 
34. Simons, T.J.; Lam, D.C.L. Documentation of a two-dimensional model package for computing lake circulation and pollutant transport. In Physics Based Modelling of Lakes, Reservoirs, and Impoundments; Gray, W.G., Ed.; ASCE: New York, NY, USA, 1986; pp. 258-308.

35. Koutitas, C.; Gousidou-Koutita, M. A comparative study of three mathematical models for wind-generated circulation in coastal areas. Coast. Eng. 1986, 10, 127-138. [CrossRef]

36. Wu, J.; Tsanis, I.K. A vertical/horizontal integration wind-induced circulation model (VH13D): A method for including surface and bottom logarithmic profiles. Adv. Water Resour. 1995, 18, 77-87. [CrossRef]

37. Lin, Y.-T.; Wu, C.H. The role of rooted emergent vegetation on periodically thermal-driven flow over a sloping bottom. Environ. Fluid Mech. 2014, 14, 1303-1334. [CrossRef]

38. Lin, Y.-T.; Wu, C.H. Effects of a sharp change of emergent vegetation distributions on thermally driven flow over a slope. Environ. Fluid Mech. 2015, 15, 771-791. [CrossRef]

39. Lin, Y.-T. Wind effect on diurnal thermally driven flow in vegetated nearshore of a lake. Environ. Fluid Mech. 2015, 15, 161-178. [CrossRef]

40. Botte, V.; Kay, A. A model of the wind-driven circulation in Lake Baikal. Dyn. Atmos. Ocean. 2002, 35, $131-152$. [CrossRef]

41. Koçyigit, M.B.; Falconer, R.A. Three-dimensional numerical modelling of wind-driven circulation in a homogeneous lake. Adv. Water Resour. 2004, 27, 1167-1178. [CrossRef]

42. Vilas, M.P.; Marti, C.L.; Adams, M.P.; Oldham, C.E.; Hipsey, M.R. Invasive macrophytes control the spatial and temporal patterns of temperature and dissolved oxygen in a shallow lake: A Proposed Feedback Mechanism of Macrophyte Loss. Front. Plant Sci. 2017, 8. [CrossRef] [PubMed]

43. Wu, C.H.; Yuan, H.; Young, C.-C. Non-hydrostatic modeling of vegetation effects on wave and flow motions. In Estuarine and Coastal Modeling (2007); American Society of Civil Engineers: Reston, VA, USA, 2008; pp. 304-321.

44. Kamarainen, A.M.; Yuan, H.; Wu, C.H.; Carpenter, S.R. Estimates of phosphorus entrainment in Lake Mendota: A comparison of one-dimensional and three-dimensional approaches. Limnol. Oceanogr. Methods 2009, 7, 553-567. [CrossRef]

45. Baumann, P.; Kitchell, J.; Magnuson, J.; Kayes, T. Lake Wignra, 1837-1973: A case history of human impact. Trans. Wis. Acad. Sci. Arts Lett. 1974, 62, 57-94.

46. Carpenter, S.R.; Benson, B.J.; Biggs, R.; Chipman, J.W.; Foley, J.A.; Golding, S.A.; Hammer, R.B.; Hanson, P.C.; Johnson, P.T.J.; Kamarainen, A.M.; et al. Understanding Regional Change: A comparison of two lake districts. Bioscience 2007, 57, 323-335. [CrossRef]

47. Carpenter, S.R. Enrichment of Lake Wingra, Wisconsin, by Submersed Macrophyte Decay. Ecology 1980, 61, 1145-1155. [CrossRef]

48. Trebitz, A.S.; Nichols, S.A.; Carpenter, S.R.; Lathrop, R.C. Patterns of vegetation change in Lake Wingra following a Myriophyllum spicatum decline. Aquat. Bot. 1993, 46, 325-340. [CrossRef]

49. Lin, Y.-T.; Wu, C.H. Response of bottom sediment stability after carp removal in a small lake. Ann. Limnol. Int. J. Limnol. 2013, 49, 157-168. [CrossRef]

50. Nichols, S.A. Factors influencing the distribution of eurasian watermilfoil (Myriophyllum spicatum L.) Biomass in Lake Wingra, Wisconsin. J. Freshw. Ecol. 1994, 9, 145-151. [CrossRef]

51. Nichols, S.A.; Mori, S. Littoral macrophyte vegetation of Lake Wingra-An example of MyriophyllumSpicatum invasion in a southern Wisconsin lake. Trans. Wis. Acad. Sci. Arts Lett. 1971, 59, 107-120.

52. Irwin, J.S. A theoretical variation of the wind profile power-law exponent as a function of surface roughness and stability. Atmos. Environ. 1979, 13, 191-194. [CrossRef]

53. Wüest, A.; Lorke, A. Small-scale hydrodynamics in lakes. Annu. Rev. Fluid Mech. 2003, 35, $373-412$. [CrossRef]

54. Wu, C.H.; Yuan, H. Efficiency and accuracy of non-hydrostatic modeling of free-surface flows. In Estuarine and Coastal Modeling (2005); American Society of Civil Engineers: Reston, VA, USA, 2006; pp. 434-447.

55. Arakawa, A. Computational design for long-term numerical integration of the equations of fluid motion: Two-dimensional incompressible flow. Part I. J. Comput. Phys. 1966, 1, 119-143. [CrossRef]

56. Pacanowski, R.C.; Gnanadesikan, A. transient resp onse in a Z-level ocean model that resolves topography with partial cells. Mon. Weather Rev. 1998, 126, 3248-3270. [CrossRef]

57. Yuan, H.; Wu, C.H. Fully Nonhydrostatic modeling of surface waves. J. Eng. Mech. 2006, 132, 447-456. [CrossRef] 
58. Yuan, H.; Wu, C.H. An implicit three-dimensional fully non-hydrostatic model for free-surface flows. Int. J. Numer. Methods Fluids 2004, 46, 709-733. [CrossRef]

59. Haidvogel, D.; Beckmann, A. Numerical models of the coastal ocean. In The Sea. The Global Coastal Ocean: Processes and Methods; Brink, K., Robinson, A., Eds.; John Wiley \& Sons, Ltd.: Hoboken, NJ, USA, 1998.

60. Wu, C.H.; Yuan, H. Efficient non-hydrostatic modelling of surface waves interacting with structures. Appl. Math. Model. 2007, 31, 687-699. [CrossRef]

61. Wu, C.H.; Young, C.-C.; Chen, Q.; Lynett, P.J. Efficient nonhydrostatic modeling of surface waves from deep to shallow Water. J. Waterw. Port Coast. Ocean Eng. 2010, 136, 104-118. [CrossRef]

62. Young, C.-C.; Wu, C.H.; Liu, W.-C.; Kuo, J.-T. A higher-order non-hydrostatic $\sigma$ model for simulating non-linear refraction-diffraction of water waves. Coast. Eng. 2009, 56, 919-930. [CrossRef]

63. Venayagamoorthy, S.K. Nonhydrostatic and nonlinear contributions to the energy flux budget in nonlinear internal waves. Geophys. Res. Lett. 2005, 32, L15603. [CrossRef]

64. Vitousek, S.; Fringer, O.B. Physical vs. numerical dispersion in nonhydrostatic ocean modeling. Ocean Model. 2011, 40, 72-86. [CrossRef]

65. García, M.H.; López, F.; Dunn, C.; Alonso, C.V. Flow, turbulence, and resistance in a flume with simulated vegetation. In Riparian Vegetation and Fluvial Geomorphology; American Geophysical Union: Washington, DC, USA, 2004; pp. 11-27.

66. Smagorinsky, J. General circulation experiments with the primitive equations. Mon. Weather Rev. 1963, 91, 99-164. [CrossRef]

67. Kantha, L.H.; Clayson, C.A. On the effect of surface gravity waves on mixing in the oceanic mixed layer. Ocean Model. 2004, 6, 101-124. [CrossRef]

68. Fischer-Antze, T.; Stoesser, T.; Bates, P.; Olsen, N.R.B. 3D numerical modelling of open-channel flow with submerged vegetation. J. Hydraul. Res. 2001, 39, 303-310. [CrossRef]

69. Nicholas, A.R.; McLelland, S.J. Computational fluid dynamics modelling of three-dimensional processes on natural river floodplains. J. Hydraul. Res. 2004, 42, 131-143. [CrossRef]

70. Jin, K.-R.; Hamrick, J.H.; Tisdale, T. Application of three-dimensional hydrodynamic model for Lake Okeechobee. J. Hydraul. Eng. 2000, 126, 758-771. [CrossRef]

71. Hirsch, C. Numerical Computation of Internal and External Flows. Computational Methods for Inviscid and Viscous Flows; John Wiley \& Sons, Ltd.: Chichester, UK, 1990.

72. Woodward, B.L.; Marti, C.L.; Imberger, J.; Hipsey, M.R.; Oldham, C.E. Wind and buoyancy driven horizontal exchange in shallow embayments of a tropical reservoir: Lake Argyle, Western Australia. Limnol. Oceanogr. 2017, 62, 1636-1657. [CrossRef]

73. Markfort, C.D.; Perez, A.L.S.; Thill, J.W.; Jaster, D.A.; Porté-Agel, F.; Stefan, H.G. Wind sheltering of a lake by a tree canopy or bluff topography. Water Resour. Res. 2010, 46. [CrossRef]

74. Magee, M.R.; Wu, C.H. Effects of changing climate on ice cover in three morphometrically different lakes. Hydrol. Process. 2017, 31, 308-323. [CrossRef]

75. Pan, H.; Avissar, R.; Haidvogel, D.B. Summer circulation and temperature structure of Lake Kinneret. J. Phys. Oceanogr. 2002, 32, 295-313. [CrossRef]

76. Rueda, F.J.; Schladow, S.G. Dynamics of large polymictic lake. II: Numerical simulations. J. Hydraul. Eng. 2003, 129, 92-101. [CrossRef]

77. Rosati, A.; Miyakoda, K. A general circulation model for upper ocean simulation. J. Phys. Oceanogr. 1988, 18, 1601-1626. [CrossRef]

78. Imberger, J.; Patterson, J.C. Physical Limnology. In Advances in Applied Mechanics; Hutchinson, J.W., Wu, T.Y., Eds.; Academic Press: Cambridge, MA, USA, 1989; pp. 303-475.

79. Horn, D.A.; Imberger, J.; Ivey, G.N. The degeneration of large-scale interfacial gravity waves in lakes. J. Fluid Mech. 2001, 434. [CrossRef]

80. Dorostkar, A.; Boegman, L.; Pollard, A. Three-dimensional simulation of high-frequency nonlinear internal wave dynamics in Cayuga Lake. J. Geophys. Res. Ocean. 2017, 122, 2183-2204. [CrossRef]

81. Meire, D.W.S.A.; Kondziolka, J.M.; Nepf, H.M. Interaction between neighboring vegetation patches: Impact on flow and deposition. Water Resour. Res. 2014, 50, 3809-3825. [CrossRef]

82. Tsujimoto, T.; Kitamura, T. Lateral bed-load transport and sand-ridge formation near vegetation zone in an open channel. J. Hydrosci. Hydraul. Eng. 1995, 13, 35-45. 
83. Nezu, I.; Onitsuka, K. Turbulent structures in partly vegetated open-channel flows with LDA and PI V measurements. J. Hydraul. Res. 2001, 39, 629-642. [CrossRef]

84. Nadaoka, K.; Yagi, H. Shallow-water turbulence modeling and horizontal large-eddy computation of river Flow. J. Hydraul. Eng. 1998, 124, 493-500. [CrossRef]

85. Xiaohui, S.; Li, C.W. Large eddy simulation of free surface turbulent flow in partly vegetated open channels. Int. J. Numer. Methods Fluids 2002, 39, 919-937. [CrossRef]

86. Davies, A.M.; Jones, J.E.; Xing, J. Review of recent developments in tidal hydrodynamic modeling. II: Turbulence energy models. J. Hydraul. Eng. 1997, 123, 293-302. [CrossRef]

87. Chen, Y.; Lei, Z. A study of eddy viscosity coefficient in numerical tidal simulation. China Ocean Eng. 2001, 15, 241-252.

88. Rubol, S.; Ling, B.; Battiato, I. Universal scaling-law for flow resistance over canopies with complex morphology. Sci. Rep. 2018, 8, 4430. [CrossRef] [PubMed]

(C) 2019 by the authors. Licensee MDPI, Basel, Switzerland. This article is an open access article distributed under the terms and conditions of the Creative Commons Attribution (CC BY) license (http:/ / creativecommons.org/licenses/by/4.0/). 